\title{
Penerapan Kebijakan Izin Belajar Dan Tugas Belajar Bagi Aparatur Sipil Negara (ASN) Di Pemerintah Kota Pekanbaru
}

\author{
${ }^{1}$ Ika Harmei Salina, ${ }^{2}$ Meyzi Heriyanto, ${ }^{3}$ Bunga Chintia Utami \\ ${ }^{12}$ Program Pasca Sarjana Ilmu Administrasi Universitas Riau \\ 3Program Studi Ekonomi Pembangunan Universitas Riau \\ e-mail: ikaharmeisalina657@gmail.com
}

\begin{abstract}
Abstrak
Penelitian ini dilatarbelakangi oleh surat edaran MENPANRB No 4 Tahun 2013 Tentang pelaksanaan izin belajar dan tugas belajar di setiap Instansi. Tujuan penelitian ini untuk menganalisis penerapan kebijakan izin belajar dan tugas belajar bagi Aparatur Sipil Negara (ASN) di Pemerintah Kota Pekanbaru. Penelitian ini menggunakan pendekatan metode penelitian kualitatif, teknik pengumpulan data melalui wawancara, observasi dan dokumentasi dari key informan. Yaitu Kepala Badan Kepegawain Daerah, Kepala Bidang Pengembangan Kompetensi Aparatur Sipil Negara, Kepala Sub bidang peningkatan pendidikan ASN, Serta perwakilan ASN kota pekanbaru. Hasil Prenelitian ini menunjukkan bawah penerapan kebijakan izin belajar dan tugas belajar bagi aparatur Sipil Negara (ASN) di Pemerintah Kota Pekanbaru berjalan dengan baik. Berdasarkan hasil dilapangan jadi dapat disimpulkan Jumlah keseluruhan Aparatur Sipil Negara (ASN) se-kota pekanbaru adalah 7.531 orang, sedangkan yang melanjutkan studiterakhir tahun 2020 adalah berjumlah 461 orang.
\end{abstract}

Kata Kunci : Penerapan Kebijakan, Izin Belajar dan Tugas Belajar

\begin{abstract}
This research was motivated by the circular letter MENPANRB No. 4 of 2013 concerning the implementation of study permits and study assignments in each agency. The purpose of this research is to implement the policy of study permits and study assignments for the Arataur Sipil Negara (ASN) in the Pekanbaru City Government. This study uses a qualitative research approach, data interview techniques, observation and documentation from key informants. Namely the Head of the Regional Civil Service Agency, the Head of the Competence Development Division for the State Civil Apparatus, the Head of the Sub-sector for improving ASN education, as well as representatives of the Pekanbaru city Paratur Sipil Negara (ASN). The results of this research show that the basis for the application of study permits and study assignments for Aparatur Sipil Negara (ASN) in Pekanbaru City Government is running well. Based on the results in the field, the total number of Aparatur Sipil Negara (ASN) in Pekanbaru is 7,531 people, while those who continue their studies at the end of 2020 are 461 people.
\end{abstract}

Keywords:Policy Implementation, Study Permit and Study Assignments

\section{PENDAHULUAN}

Pemerintah kota Pekanbaru memiliki visi yakni "Meningkatkan Sumber Daya Manusia (SDM) yang Bertaqwa, Mandiri, Tangguh dan Berdaya Saing Tinggi," dalam hal ini pemerintah kota Pekanbaru terus melakukan reformasi pelayanan pemerintahannya agar visi yang sudah digagas tersebut dapat segera tercapai. untuk meningkatkan pelayanan yang diberikan oleh pemerintah kota Pekanbaru diperlukan sumber daya manusia yang handal dan tepat pada tugas dan fungsinya masing-masing, keseriusan pemerintah kota Pekanbaru untuk meningkatkan sumber daya manusia dilihat dari salah satu misi kota Pekanbaru adalah "Mewujudkan sumberdaya manusia yang berkualitas dan berdaya beriman dan bertaqwa serta mampu bersaing ditingkat lokal, nasional, maupun internasional".Sejalan dengan cita-cita 
pemerintah akan mewujudkan Pegawai Negeri Sipil yang Profesional tentunya Sumber Daya Manusia yang berkualitas. Dalam upaya itu peningkatan kualitas Sumber Daya Manusia khususnya Sumber Daya Aparatur menjadi prioritas utama adalah beberapa cara yang dapat dilakukan antara lain dapat melalui Pendidikan dan pelatihan.

Aparatur Sipil Negara (ASN) sebagai alat pemerintah (aparatur pemerintah) memiliki keberadaan yang sentral dalam membawa komponen kebijaksanaan atau peraturan-peraturan pemerintah guna terealisasinya tujuan nasional. Komponen tersebut terakumulasi dalam bentuk pendistribusian tugas, fungsi, dan kewajiban ASN. Dengan adanya peregeseran paradigma dalampelayanan publik, secara otomatis hal tersebut akan menciptakan perubahan sistem dalam hukum kepegawaian dengan adanya penyesuaian-penyesuaian dalam pelaksanaan tugas, fungsi dan kewajiban, dari ASN meliputi penataan kelembagaan birokrasi pemerintahan, sistem, dan penataan manajemen kepegawaian ${ }^{1}$

Peraturan Pemerintah (PP) no 11 Tahun 2017 tentang Manajemen Pegawai Negeri Sipil diantaranya berisi ketentuan mengenai penyusunan dan penetapan kebutuhan, pengadaan, pangkat dan jabatan, pengembangan karier, pola karier, promosi, mutasi, penilaian kinerja, penggajian dan tunjangan, penghargaan, disiplin, pemberhentian, jaminan pensiun dan jaminan hari tua, serta perlindungan. Peraturan Pemerintah Republik Indonesia Nomor 11 Tahun 2017 tentang Manajemen Pegawai Negeri Sipil ditetapkan pada tanggal 30 Maret 2017 di Jakarta oleh Presiden Joko Widodo. Peraturan Pemerintah Nomor 11 Tahun 2017 tentang Manajemen Pegawai Negeri Sipil mulai berlaku pada tanggal 7 April 2017 setelah diundangkan oleh Menkumham Yasonna H. Laoly di Jakarta.

Undang undang nomor 5 tahun 2014 tentang Aparatur Sipil Negara menjadi pemicu untuk merealisasikan terwujudnya Sumber Daya Manusia dalam hal ini Sumber Daya Aparatur yang berkualitas, mempunyai Kompetensi dibidangnya, profersional dalam berekerja serta berdaya saing tinggi dalam mengejar kualitas kerja. Sehingga kedepan pemerintah tidak akan ragu membuat/merancang program untuk pembangunan terkhusus sumber daya aparatur yang bermuara pada pemenuhan kebutuhan dan pelayanan kepada masyarakat, dalam peningkatan pelayanan baik yang bersipat internal maupun pelayanan yang bersipat eksternal. Pasal 3 angka 16 Peraturan Pemerintah Nomor 53 Tahun 2010 tentang Disiplin Pegawai Negeri Sipil (PP 53/2010) menentukan bahwa setiap Pegawai Negeri Sipil (PNS) wajib memberikan kesempatan kepada bawahan untuk mengembangkan karier. Yang dimaksud dengan "memberikan kesempatan kepada bawahan untuk mengembangkan karier" adalah memberi kesempatan kepada bawahan untuk meningkatkan kemampuan dalam rangka pengembangan karier, antara lain memberi kesempatan mengikuti rapat, seminar, diklat, dan pendidikan formal lanjutan. Pemberian Izin Belajar ASN Dalam hal seorang ASN ingin melanjutkan pendidikan ke jenjang yang lebih tinggi, sebagaimana yang diatur dalam Surat Edaran Menteri Pendayagunaan Aparatur Negara dan Reformasi Birokrasi Nomor 04 Tahun 2013 tentang Pemberian Tugas Belajar dan lzin Belajar Bagi Pegawai Negeri Sipil (SE MENPAN RB 4/2013), ketentuan pemberian izin belajar kepada PNS.

Aparatur Sipil Negara melaksanakan tugas nya tersebut secara profesional dan bertanggung jawab dalam menyelenggarakan tugas pemerintahan dan pembangunan, serta bersih dan bebas dari korupsi, kolusi dan nepotisme. Sebagai motor penggerak dalam penyelenggaraan pemerintahan dan pelaksanaan pembangunan, dalam pelaksanaan tugas, ASN diharapkan fokus mencurahkan segala potensi dan perhatiannya untuk mensukseskan pencapaian tujuan organisasinya. Segala hal yang akan mengganggu dan menjadi pemecah konsentrasi haruslah diminimalisir.

Badan Kepegawaian dan Pengembangan Sumber Daya Manusia selaku perangkat daerah, yang salah satu tugasnya adalah memberikan pelayanan kepegawaian kepada ASN. Dalam memberikan pelayanan kepegawaian, perlu diberikan informasi yang lengkap terkait pelayanan itu. Layanan

${ }^{1}$ Hery Kurnia Sulistyadi, 'Implementasi Kebijakan Penyelenggaraan Layanan Pendidikan Inklusif Di Kabupaten Sidoarjo', Kebijakan Dan Manajemen Publik, 2.1 (2014), 1-10. 
kepegawaian haruslah tersosialisasi dengan sempurna, sehingga semua ASN tahu dan memahami segala hal terkait dengan layanan tersebut. Salah satu persyaratan untuk menciptakan pelayanan yang baik adalah adanya kejelasan tentang layanan itu, baik aturan yang mengaturnya, manfaat, persyaratan, maupun prosedur pengurusannya.

Pengembangan kualitas merupakan suatu keharusan dalam pemerintahan untuk mencapai hasil yang maksimal dalam pelaksanaan pekerjaaannnya. Permasalahan yang terjadi dalam struktur birokrasi Indonesia adalah rendahnya kualitas PNS dan kurang memiliki daya saing dalam menghadapi era globalisasi. Salah satu upaya untuk meningkatkan kualitas PNS yaitu, dengan melanjutkan pendidikan. Dalam Undang-Undang Nomor 20 Tahun 2003 Tentang Sistem Pendidikan Nasional memberikan pengertian bahwa Pendidikan adalah usaha sadar dan terencana untuk mewujudkan suasana belajar dan proses pembelajaran agar peserta didik secara aktif mengembangkan potensi dirinya untuk memiliki kekuatan spiritual keagamaan, pengendalian diri, kepribadian, kecerdasan, akhlak mulia, serta keterampilan yang diperlukan dirinya, masyarakat, bangsa, dan negara. Artinya pendidikan sangatlah penting dan juga berlaku bagi PNS dalam mengembangkan kualitas dan kinerjanya.

Ketentuan umum peraturan Menteri Pemberdayaan Aparatur Negara dan Reformasi Birokrasi tersebut diatas menyebutkan bahwa Pegawai Negeri Sipil adalah warga negara Indonesia yang memenuhi syarat tertentu, diangkat sebagai Pegawai Aparatur Sipil Negara (ASN) secara tetap oleh pejabat pembina Kepegawaian untuk menduduki jabatan pemerintah. Jabatan yang dipangku menjadi tanggung jawab bagi PNS yang bersangkutan dengan memperlihatkan dan menunjukan kemapuan kerja yang Profesional. Disisi lain pemerintah berperan sangat besar dalam memberikan pembinaan dengan segala fasititas yang mumpuni serta diiringi dengan pengawasan.

Kondisi nyata dilapangan bahwa untuk peningkatan mutu kerja pegawai masih banyak yang perlu lebih fokus terhadap penerapan melalui pelatihan pelatihan, karna untuk mendapatkan hasil kerja yang maksimal, berkualitas, bermutu dan dilengkapi kecakapan/keterampilan tentunya membutuhkan pengetahuan dan keahlian yang memadai. Suatu organisasi akan dapat menjalankan fungsinya dengan efektif dan efisien, apabila didukunng dengan kualitas dan kuantitas sumber daya aparatur yang memiliki kompetensi dibidangnya ${ }^{2}$.

Kompetensi yang dituntut tentu berbanding lurus antar kompetensi Tekhnis/Pendidikan, Kompetensi Managerial dan kompetensi Sosial seperti yang sudah dicanangkan dalam UU No 5 th 2014 ttg Aparatur Sipil Negara. Pada pasal 70 dituangkan pada ayat (1) bahwa setiap pegawai memiliki hak dan kesempatan untuk mengembangkan Kompetensi. Artinya PNS harus mendapat pendidikan baik formal maupun Informal.suatu negara yang baik ialah negara yang diperintah dengan konstitusi dan kedaulatan hukum. Pemerintahan yang berkonstitusi yaitu Pemerintahan yang dilaksanakan untuk kepentingan umum, pemerintahan yang dilaksanakan menurut hukum berdasarkan pada ketentuanketentuan umum, dan pemerintahan yang dilaksanakan atas kehendak rakyat, bukan berupa paksaantekanan yang dilaksanakan pemerintahan despotik.

Permasalahan untuk meningkatkan SDM bagi Aparatur Sipil Negara tidak sesuai dan tidak sejalan dengan undang-undang dan peraturan yang telah dibuat oleh pemerintah itu sendiri, karena saat ini banyak terdapat permasalah tentang pengurusan izin belajar dan tugas belajar sangat sulit, berdasarkan informasi media bahwa 50\% prosedur izin belajar dan tugas belajar menuai masalah.http://pekanbaru.tribunnews.com. Peningkatan kualitas Sumber Daya Manusia di lingkungan pemerintah salah satunya adalah memberikan kesempatan dan peluang sebesar-besarnya bagi Aparatur Sipil Negara untuk melanjutkan jenjang pendidikan formal seperti dari sarjana menuju magister dan dari magister menuju doktor dengan prosedur dan kebijakan memberikan izin yang mudah dan tidak berliku-

${ }^{2}$ Sri Suwitri, 'Konsep Dasar Kebijakan Publik MODUL 1', Analisis Kebijakan Publik, 2, 2014, 1-51

<https://doi.org/http://dx.doi.org/10.1016/j.atmosenv.2007.12.054>. 
liku agar SDM yang unggul dan profesional itu dimiliki oleh pemerintah. Berdasarkan uraian latar belakang diatas dan peraturan pemerintah daerah melalui Undang-Undang, maka untuk menfokus penelitian ini, peneliti tertarik meneliti tentang Penerapan Kebijakan Izin Belajar dan Tugas Belajar Bagi Aparatur Sipil Negara (ASN) Di Pemerintah Kota Pekanbaru

\section{METODE}

Jenis penelitian ini adalah penelitian kualitatif dengan pendekatan fenomenologi. Fenomenologi adalah pendekatan yang dimulai oleh Edmund Husserl dan dikembangkan oleh Martin Heidegger untuk memahami atau mempelajari pengalaman hidup manusia. Pendekatan ini berevolusi sebuah metode penelitian kualitatif yang matang dan dewasa selama beberapa dekade pada abad ke dua puluh. Fokus umum penelitian ini untuk memeriksa/meneliti esensi atau struktur pengalaman ke dalam kesadaran manusia (Tuffour: 2017).Penelitian ini dilakukan di Kota Pekanbaru tepatnya pada Badan Kepegawaian Dan Pengembangan Sumber Daya Manusia Beberapa pertimbangan tertentu yang peneliti Pertimbangan pertama adalah unsur keterjangkauan lokasi penelitian oleh peneliti, baik dilihat dari segi tenaga, dana maupun dari segi efisiensi waktu.Adapun metode pengumpulan data yang penulis gunakan dalam penelitian ini adalah observasi, wawancara dan dokumentasi

Informan adalah subjek yang memberikan data berupa informasi kepada peneliti. Dalam penelitian ini peneliti menggunakan teknik purposive sampling dimana peneliti memilih key informan dan informan yang peneliti anggap mengetahui tentang permasalahan penelitian. Sebagai key informan yang paling mengetahui tentang peranan Badan Kepegawaian Dan Pengembangan Sumber Daya Manusia dalam memberikan izin belajar dan tugas belajar terhadap ASN Kota pekanbaru. Adapun yang menjadi informan yang akan memberikan keterangan tambahan demi mendapatkan data yang utuh dalam penelitian ini adalah :

1) Kepala Badan Kepegawaian Daerah Kota Pekanbaru

2) Kepala Bidang Pengadaan Pegawai dan Sistem Informasi

3) Kepala Sub Bagian Peningkatan Pendidikan PNS

\section{HASIL DANPEMBAHASAN}

Hasil penelitian Ilmiah memerlukan data yang akurat dan disusun dengan metode tertentu, sehingga nantinya akan ditemukan hasil yang valid. Selain itu juga sistematika penulisan dari sisi bahasa maupun isinya dapat dipertanggung jawabkan keilmiahannya. Penelitian ini membahas teori yang dikemukakan oleh Ripley dan Franklin untuk menjawab permasalahan penelitian, sehinggga diharapkan nantinya antara teori dan kenyataan lapangan dapat disesuaikan dalam menyelesaikan permasalahan penerapan kebijakan izin belajar dan tugas belajar bagi Aparatur Sipil Negara (ASN) di pemerintahan kota pekanbaru.

Jenis penelitian ini adalah penelitian kualitatif dengan pendekatan fenomenologi. Pendekatan ini berevolusi sebuah metode penelitian kualitatif yang matang dan dewasa selama beberapa dekade pada abad ke dua puluh. Fokus umum penelitian ini untuk memeriksa/meneliti esensi atau struktur pengalaman ke dalam kesadaran manusia.Penilaian dengan menggunakan analisis kualitatif yaitu suatu teknik menganalisa data menggambarkan secara utuh kenyataan mengenai permasalahan yang diteliti. Penilaian dengan menggunakan analisa kualitatif dilakukan untuk mengetahui penerapan kebijakan izin belajar dan tugas belajar bagi Aparatur Sipil Negara (ASN) di pemerintahan kota pekanbaru. 
Penelitian dilakukan dengan menggunakan metode snowball sampling yaitu sebuah teknik penentuan sumber informasi yang paling tepat dalam memberikan tanggapan tentang penerapan kebijakan izin belajar dan tugas belajar bagi Aparatur Sipil Negara (ASN) di pemerintahan kota pekanbaru. Setelah itu akan digunakan metode triangulasi dengan cek and cross cek terhadap hasil tanggapan yang diberikan subjek penelitian. Pada proses wawancara penelituan penulis langsung melakukan tanya jawab kepada subjek penelitian yang sudah ditetapkan, agar data yang diberikan benar-benar akurat.untuk mengetahui hasil penelitian dan pembahasan dari penerapan kebijakan izin belajar dan tugas belajar bagi Aparatur Sipil Negara (ASN) di pemerintahan kota pekanbaru.

Hasil penelitian ini membahas teori yang dikemukakan oleh Ripley dan Franklin dalam Fatih (2010) berdasarkan kerangka berfikir dan rumusan masalah yang peneliti susun sebagai berikut :

\section{Penerapan Kebijakan Izin Belajar Dan Tugas Belajar Bagi Aparatur Sipil Negara (ASN) di Pemerintahan Kota Pekanbaru}

\subsection{Tingkat Kepatuhan pada ketentuan yang berlaku}

Tingkat keberhasilan implementasi kebijakan dapat diukur dengan melihat tingkat kepatuhan terhadap isi kebijakan dengan peraturan yang telah diatur. Ripley memperkenalkan pendekatan "kepatuhan" dan pendekatan "faktual". Pendekatan ini memusatkan perhatian pada tingkat kepatuhan lembaga atau individu bawahan terhadap lembaga atau individu atasan.

Pada Tanggal 11 Desember tahun 2020 Peneliti melakukan wawancara dengan Ibu Dinal Husna, SH, M.Si (Kepala Bidang Pengembangan Kompetensi ASN) dengan pertanyaan bagaimana tingkat kepatuhan Aparatur Sipil Negara (ASN) yang melanjutkan studi izin belajar dan tugas belajar di pemerintah kota pekanbaru,?, ibu Dinal Husan langsung menjawab bahwa :

Tingkat kepatuhan Aparatur Sipil Negara (ASN) yang melanjutkan studi izin belajar dan tugas belajar di pemerintah kota pekanbaru sangat rendah, karena masih dapat kita temukan dilapangan bahwa masih ada Aparatur Sipil Negara (ASN) yang melanjutkan studi izin belajar dan tugas belajar yang tidak mengurus dan memperpanjang surat izin belajar dan tugas belajar nya. Hal itu nanti akan mengakibatkan kepada yang bbersangkutan tidak akan dapat pengakuan dari pemerintahan setelah menyelesaikan studi nya.

Pertanyaan selanjutnya adalah jika Aparatur Sipil Negara (ASN) yang melanjutkan studi izin belajar dan tugas belajar di pemerintah kota pekanbaru, apakah ada Sanksi dari Pemerintah Kota Pekanbaru,? Ibu Dinal Husna juga menjawab :

Tidak ada sanksi dari Pemerintah Kota Pekanbaru, Karena Aparatur Sipil Negara (ASN) yang melanjutkan studi izin belajar dan tugas belajar di Pemerintah Kota Pekanbaru rata-rata menggunakan biaya pribadi, jika ada yang mendapatkan biaya dari pemerintah seperti beasiswa dari Kemenkes, Kemenkeu dan Kemendikbud serta dari Pihak memberi Beasiswa Lainnya, Maka yang akan berhak memberikan sanksi adalah Pihak yang memberikan beasiswa terhdap Aparatur Sipil Negara (ASN) yang melanjutkan studi izin belajar dan tugas belajar tersebut.

Menyambung jawaban diatas peneliti kembali menanyakan terkait diatas, jadi pemerintah kota pekanbaru tidak dapat memberikan sanksi, karena yang memberikan beasiswa bukan dari pemerintah kota pekanbaru, pertanyaan nya adalah apakah pemerintah kota pekanbaru tidak menyediakan anggaran untuk beasiswa bagi Aparatur Sipil Negara (ASN) yang melanjutkan studi izin belajar dan tugas belajar nya,???, Karena Program tentang izin belajar dan tugas belajar salah satu program yang dapat menyalurkan dalam peningkatan kompetensi ASN dalam meningkatkan Sumber Daya Manusia. Ibu Dinal Husna sebagai Kepala Bidang PKA langsung menjawab :

Sepanjang pengetahuan kami, dan selama saya menjabat sampai saat ini, memang belum ada pemerintah kota pekanbaru menganggarkan anggaran beasiswa untuk Aparatur Sipil Negara (ASN) yang melanjutkan studi izin belajar dan tugas belajar di Pemerintah Kota Pekanbaru. 
Dapat disimpulkan dari pertanyaan dan jawaban diatas adalah masih terdapat dilapangan Aparatur Sipil Negara (ASN) yang melanjutkan studi izin belajar dan tugas belajar di pemerintah kota pekanbaru yang belum patuh terhadap peraturan yang berlaku, namun untuk sanksi terhadap masalah tersebut pemerintah kota pekanbaru tidak dapat memberikan sanksi, karena pemerintah kota pekanbaru belum ada menganggarkan anggaran untuk beasiswa bagi Aparatur Sipil Negara (ASN) yang melanjutkan studi izin belajar dan tugas belajar.

\subsection{Kelancaran Rutinitas Program dan Masalahnya}

Kelancaran rutinitas program izin belajar dan tugas belajar bagi Aparatur Sipil Negara (ASN) di Kota Pekanbaru, tentu diperlukan kebijakan yang baik dari setiap kepala daerah untuk mengatasi masalah yang akan muncul dikemudian hari. Dalam Hal ini Badan kepegawain daerah Kota Pekanbaru berindak sebagai pelaksana program izin belajar dan tugas belajar sesuai dengan aturan yang berlaku. Untuk kelancaran program tersebut harus ada sistem yang mempermudah orang lain untuk melaksanakannya, Hal ini dapat peneliti telusuri melalui hasil penelitian dengan mewawancarai ibu Dinal Husna sebagai Kabid PKA tentang masalah Aparatur sipil negara (ASN) kota pekanbaru mengajukan permohonan izin belajar dan tugas belajar, untuk mempermudah ASN pemerintah kota pekanbaru harus menyiapkan petunjuk teknis dan sosialisasi kepada ASN yang ingin melanjutkan studi kejenjang yang lebih tinggi kepada Badan Kepegawain Daerah (BKD) kota pekanbaru. Maka dalam Hal tersebut peneliti langsung memberikan pertanyaan selanjutnya dengan pertanyaan Apakah ada petunjuk teknis atau alur pengajuan Izin dari pemerintah daerah untuk ASN yang ingin melanjutkan studi dengan izin belajar dan tugas belajar,? Ibu Dinal Husna hanya menjawab :

Bahwa pemerintah kota pekanbaru hanya mengacu pada MENPAN RB No 4 Tahun 2013, sampai saat ini belum ada peraturan daerah kota pekanbaru yang mengatur sendiri tentang penerapan kebijakan izin belajar dan tugas belajar bagi aparatur sipil negara (ASN) dilingkungan kota pekanbaru.

Peneliti belum mendapatkan petunjuk teknis tentang bagaimana alur proses pengajuan izin belajar dan tugas belajar yang ditetapkan atau diatur sendiri oleh pemerintah kota pekanbaru di lingkungan pemerintah kota pekanbaru, Namun berdasarkan jawaban diatas peneliti dapat memberikan hasil penelitian bagi aparatur Sipil Negara (ASN) se-kota pekanbaru yang ingin melanjutkan studi izin belajar dan tugas belajar dapat mengacu pada peraturan pemerintah pusat melalui surat edaran MENPAN RB No. 4 Tahun 2013. Selanjutnya ibu Kabid Dinal Husna, SH, M.Si menagatakan bagi aparatur Sipil Negara (ASN) se-kota pekanbaru yang ingin melanjutkan studi izin belajar dan tugas belajar dapat mengajukan secara online melalui Aplikasi SIMPEG BKPSDM Pekanbaru atau webnya adalah simpeg.pekanbaru.go.id atau dapat dilihat pada gambar dibawah ini : 




Gambar 1 : Layar Login Aplikasi Sistem Pegawai Kota Pekanbaru Sumber : Data \&Sistem Informasi ASN BKD Kota Pekanbaru

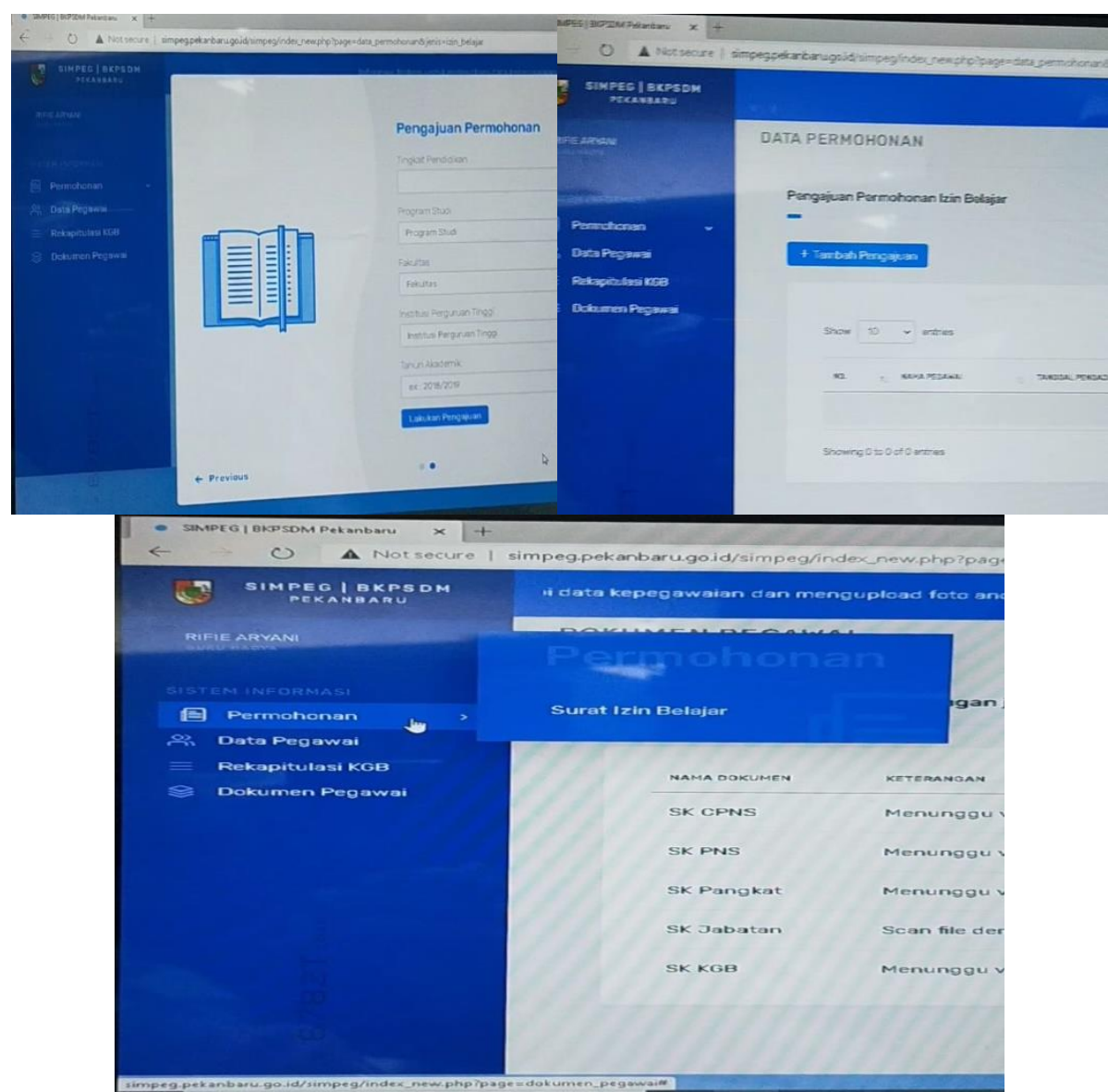

Gambar 2 : layar Aplikasi Pengajuan Permohonan Izin Belajar Sumber : Sumber : Data \&Sistem Informasi ASN BKD Kota Pekanbaru

Peneliti melanjutkan tanya jawab kepada Ibu Dinal Husna, SH, M.Si Kepala Bidang Pengembangan Kompetensi ASN BKD Kota Pekanbaru adalah Apakah ada sosialisasi tentang kebijakan izin belajar dan tugas belajar dari BKD atau pemerintah kota pekanbaru kepada aparatur sipil negara (ASN),?, Ibu Dinal Husna langsung menjawab : Untuk sosialisasi tentang izin belajar dan tugas belajar serta Hak aparatur sipil negara (ASN) di lingkungan kota pekenabru sudah 
dilakukan pada saat pembekalan Calan Pegawai Negeri Sipil (CPNS) sebelum di angkat 100\% menjadi aparatur sipil negara (ASN) di pemerintah kota pekanbaru.

\subsection{Pelaksanaan dan Dampak (Manfaat)}

Untuk melihat sejauh mana pelaksanaan penerapan izin belajar dan tugas belajar bagi ASN (Aparatur Sipil Negara) di pemerintah Kota Pekanbaru, Peneliti mencari data yang lebih mendukung, untuk melihat persentase sejauh mana tingkatan pendidikan ASN kota pekanbaru selama ini, maka peneliti melanjutkan wawancara dengan bagian Data dan Informasi ASN di BKD kota pekanbaru. Pada tanggal 23 Desember 2020 peneliti melakukan wawancara dengan Ibu Hidayati kurnia Fitri, A.Md, (Staff Administrasi Data dan Sistem Informasi ASN) dengan pertanyaan pertama berapakah jumlah keseluruhan ASN se-kota pekanbaru,? Ibu Hidayati kurnia Fitri langsung melihat data induk di kompter total keseluruhannya ASN se-kota pekanbaru dan kualifikasi pendidikannya dapat dilihat pada tambel dibaweah ini :

Tabel 1

Jumlah Aparatur Sipil Negara (ASN)Se-Kota Pekanbaru

\begin{tabular}{cccccc}
\hline $\begin{array}{c}\text { Kualifikasi } \\
\text { pendidikan }\end{array}$ & Jumlah & $\begin{array}{l}\text { Kualifikasi } \\
\text { pendidikan }\end{array}$ & Jumlah & $\begin{array}{l}\text { Kualifikasi } \\
\text { pendidikan }\end{array}$ & Jumlah \\
\hline SD & 25 & D1 & 36 & Profesi & 403 \\
\hline SMP & 46 & D2 & 270 & S1 & 4253 \\
\hline SMA & 867 & D3 & 691 & S2 & 684 \\
\hline SARJANA & & D4 & 247 & S3 & 9 \\
\hline Jumlah & 938 & Jumlah & 1244 & Jumlah & 5349 \\
\hline
\end{tabular}

Sumber : Administrasi Data dan Sistem Informasi ASN BKD Kota Pekanbaru

Berdasarkan hasil data diatas dapat peneliti jabarkan bahwa jumlah ASN yang berkualifikasi pendidikan SD, SM dan SMA adalah 938 Orang, dan jumlah ASN yang berkualifikasi pendidikan D-1, D-2, D-3 dan D-4 adalah 1.244 Orang dan selanjutnya jumlah ASN yang berkualifikasi pendidikan mulai dari profesi, S-1, S-2 dan S-3 adalah 5.349 Orang jadi dapat disimpulkan Jumlah keseluruhan ASN se-kota pekanbaru adalah 7.531 orang. Selanjutnya Pada tanggal 29 Desember 2020 peneliti melanjutkan mewawancarai ibu Ade Irma Suryani Kepala Sub Bidang Peningkatan Pendidikan PNS di Badan Kepegawaian Daerah Kota Pekanbaru dengan pertanyaan Berapakah jumlah ASN dilingkungan kota pekanbaru yang melanjutkan studi dengan program izin belajar dan tugas belajar terakhir,?. Pertanyaan itu langsung dijawab oleh ibu Ade Irma mengatakan :Sebelum kami menjawab pertanyaan tersebut, maka sebelumnya kami mintak maaf, karena kami tidak bisa menjawab maksimal seperti yang diminta, dikarnakan baru menjabat, maka data yang dapat kami berikan adalah sesuai dengan data yang kami rekap terakhir setelah kami menjabat, karena data sebelumnya adalah data manual belum online jadi kami terima dari pejabat sebelumnya.

Berdsarkan hasil wawancara dengan ibu Ade Irma Suryani (Kepala Sub Bidang Peningkatan Pendidikan PNS di Badan Kepegawaian Daerah Kota Pekanbaru) data yang diberikan dapat dilihat pada tabel dibawah ini: 
Tabel 2

Rekap ASN yang melaksanakan izin belajar tahun

Tahun 2017-2020

\begin{tabular}{lcc}
\hline \multicolumn{2}{c}{ Rekap Izin Belajar Di Sipijar Pemerintah Kota Pekanbaru } \\
\hline Bidang Pendidikan & Okt 2017 S.D Des 2019 & 2020 \\
\hline Akta IV & - & 1 \\
\hline D.III/Akademi & 2 & 10 \\
\hline D.IV & 1 & 9 \\
\hline Profesi & 2 & 11 \\
\hline S.1 & 21 & 88 \\
\hline S.2 & 18 & 75 \\
\hline Jumlah & 44 Orang & 194 Orang \\
\hline
\end{tabular}

Berdasarkan tabel diatas dapat disimpulkan bahwa jumlah ASN izin belajar yang terdaftar di sipijar pemerintah kota pekanbaru mulai tahun 2017 s.d tahun 2019 berjumlah 44 orang dan pada tahun 2020 berjumlah 194 orang. Jadi total keseluruhan nya adalah 225 Orang yang ada disipijar pemerintah kota pekanbaru.

Tabel 3

Rekap ASN yang melaksanakan izin belajar berdasarkan pendidikan terakhir tahun 2019 Rekap Berdasarkan Pendidikan Terakhir 2019

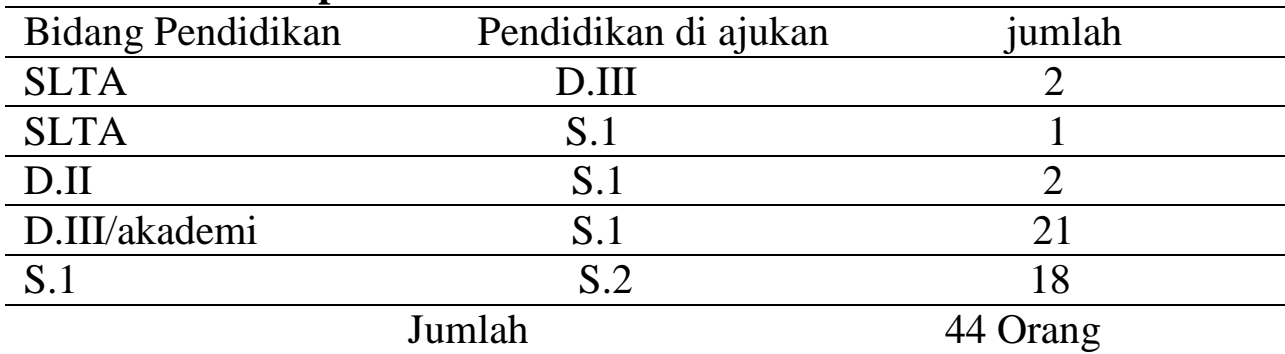

Berdasarkan tabel diatas dapat peneliti uraikan bahwa yang melanjutkan studi izin belajar berdasarkan pendidikan pada tahun 2019 adalah dari SLTA-D.III berjumlah 2 orang, SLTA-S.1 berjumlah 1 orang, D.II.Si berjumlah 2 orang, D.III/Akademi-S.1 berjumlah 21 orang, dan S.1-S.2 berjumlah 18 orang, jadi total keseluruhan yang melanjutkan studi izin belajar pada tahun 2019 adalah 44 orang.

Tabel 4

Rekap ASN yang melaksanakan izin belajar berdasarkan pendidikan terakhir tahun 2020 Rekap Berdasarkan Pendidikan Terakhir 2020

\begin{tabular}{|c|c|c|}
\hline Bidang Pendidikan & Pendidikan di ajukan & Jumlahl \\
\hline SLTA & S.1 & 88 \\
\hline D.II & S.1 & 8 \\
\hline D.III/akademi & S.1 & 3 \\
\hline D.IV & S.1 & 9 \\
\hline Profesi & S.1 & 11 \\
\hline S.1 & S.2 & 75 \\
\hline Jumlah & & 194 Orang \\
\hline
\end{tabular}


Berdasarkan tabel diatas dapat peneliti uraikan bahwa yang melanjutkan studi izin belajar berdasarkan pendidikan pada tahun 2020 adalah dari SLTA-S.1 berjumlah 88 orang, D.II-S.1 berjumlah 8 orang, D.III/Akademi-S.1 berjumlah 3 orang, D.IV-S.1 berjumlah 9 orang, ProfesiS.1 berjumlah 11 orang, dan S.1-S.2 berjumlah 75 orang jadi total keseluruhan yang melanjutkan studi izin belajar pada tahun 2020 adalah 194 orang.

\section{Tabel 5}

Jumlah ASN yang melaksanakantugas belajar tahun

Tahun 2017-2020

\begin{tabular}{lcc}
\hline \multicolumn{3}{c}{ Rekap Tugas Belajar 2017-2020 } \\
\hline Bidang Pendidikan & Pendidikan di ajukan & Jumlah \\
\hline D.III/akademi & S.1 & 14 \\
\hline SLTA & S.1 & 7 \\
\hline S.1 S.2 & Jumlah & 29 Orang \\
\hline \multicolumn{2}{c}{ Sumber : PKA BKPSDM Kota Pekanbaru }
\end{tabular}

Berdasarkan tabel diatas dapat disimpulkan bahwa ASN kota pekanbaru yang melanjutkan studi tugas belajar dari tahun 2017-2020 adalah dari pendidikan D.III/akademi-S.1 berjumlah 14 orang, SLTA-S.1 berjumlah 7 orang dan S.1-S.2 berjumlah 8 orang, jadi total keseluruhan yang melanjutkan stud tugas belajar adalah 29 orang.Selanjutnya berdasarkan Data di atas untuk melihat sejauh mana dampat atau manfaat dari penerapan kebijakan izin belajar dan tugas belajar bagi ASN (Aaparatur Sipil Negara) Di Pemerintah Kota Pekanbaru yang sudah terlaksana, Peneliti dapat menyimpulkan dalam 2 aspek yaitu dampak bagi pemerintah kota pekanbaru dan dapak bagi ASN (Aaparatur Sipil Negara).

Menjawab dua aspek diatas peneliti melakukan wawancara dengan Ibu Dinal Husna sebagai Kabid PKA di Badan Kepagawaian Daerah Kota Pekanbaru dengan pertanyaan bagaimana dampak atau manfaat bagi pemerintah kota pekanbaru dan dapak atau manfaat bagi ASN (Aaparatur Sipil Negara) terhadap penerapan kebijakan izin belajar dan tugas belajar ini,? Ibu dinal Husna menjawab bahwa :Dampak nya bagi Pemerintah Kota Pekanbaru terhadap penerapan kebijakan izin belajar dan tugas belajar adalah dapat meningkatkan Kompetensi ASN agar lebih produktif dalam melaksanakan tugasnya di pemerintah kota pekanbaru, sehingga nanti dapat menjalankan tugas dengan baik dari pimpinan dan kepala daerah kota pekanbaru dengan totalitas.

Dampak atau manfaat bagiASN (Aaparatur Sipil Negara) adalah ketika sudah selesai program izin belajar dan tugas belajar dengan mengikuti aturan berlaku ASN dapat pengakuan kenaikan pangkat dan jabatannya dalam sistem kepegawaian sehingga nanti bisa mendapatka prmosi jabatan naik dari jabayan sebelumnya.Itulah salah satu dampak dari sekian banyak dampak atau manfaat dalam penerapan kebijakan izin belajar dan tugas belajar ini.

\section{Faktor-Faktor Yang Menghambat Dalam Penerapan Kebijakan 2.1 Faktor Komunikasi}

Komunikasi dapat dimaknai sebagai jalannya proses dimana seseorang maupun sekelompok orang menciptakan serta menggunakan sejumlah informasi agar saling terhubung dengan lingkungan sekitar. Secara umum komunikasi dapat dilakukan secara verbal serta dapat dipahami oleh kedua belah pihak berkaitan.Komunikasi menurut para ahli di antaranya seperti yang disebutkan oleh Anwar Arifin. Menurutnya arti komunikasi adalah jenis proses sosial yang erat 
kaitannya dengan aktivitas manusia serta sarat akan pesan maupun perilaku. Skinner turut beropini tentang komunikasi sebagai suatu perilaku lisan maupun simbolik dimana pelaku berusaha memperoleh efek yang diinginkan.

Berdasarkan perkembangan zaman menurut peneliti komunikasi dibagi dua yaitu komunikasi langsung dan tidak langsung, untuk memperjelas hasil penelitian ini peneliti langsung melakukan wawancara pada tanggal 16 November 2020 dengan Ibu Kabid Dinal Husna dengan pertanyaan bagaimana komunikasi baik secara langsung maupun tidak langsung Aparatur Sipil Negara (ASN) di pemerintah Kota Pekanbaru yang melanjutak studi dengan program izin belajar dan tugas belajar,? Ibu Dinal Husan Menjawab : Komunikasi ASN pada saat ini sudah secara tidak langsung yaitu melalui sistem aplikasi online yang dirancang oleh Badan Kepegawaian daerah Kota Pekanbaru, Baik dalam menagjukan proses izin belajar dan tugas belajar maupun aktifitas lainnya.Komunikasi langsung sudah sangat jarang dilakukan sampai saat ini, apalagi dalam satu tahun terakhir ini semenjak Dunia, Indonesia khususnya dilanda oleh pandemi virus corona atau covid 19 ini. Semua aktifitas sudah diwajibkan secara tidak langsung.

Pertanyaan selanjutnya adalah bagaimana menurut ibu kabid Dinal Husna apakah faktor komunikasi dapat mempengaruhi dalam suatu kepengurusan atau kebijakan dalam pemerintah kota pekanbaru tentang izin belajar dan tugas belajar ini,? Ibu Dinal Husna langsung menjawab : Faktor komunikasi sangat penting dan sangat mempengaruhi dalam penerapan suatu kebijkan, apalagi dalam kepengurusan izin belajar dan tugas belajar ini, ASN (Aparatur Sipil Negara) harus di tuntut aktif dalam berkomunikasi, agar kebijakan dan tujuan tercapai sesuai dengan apa kita inginkan.

Berdasrakan pertanyaan dan jawaban diatas peneliti dapat menyimpulkan bahwa dalam penereapan kebijakan izin belajar dan tugas belajar ini ASN (Aparatur Sipil Negara) ini faktor komunikasi sangat berpengaruh, maka saran peneliti bagi ASN yang ingin melanjutkan studi izin belajar dan tugas belajar hendaknya menigkatkan jaringan kumunikasinya agar tidak ketinggalan informasi.

\subsection{Faktor Sumber daya}

Menciptakan sumber daya manusia yang berkualitas dan unggul merupakan cita-cita pemerintah daerah sampai ke pemerintah pusat. sebagaimana yang diatur dalam Surat Edaran Menteri Pendayagunaan Aparatur Negara dan Reformasi Birokrasi Nomor 04 Tahun 2013 tentang Pemberian Tugas Belajar dan lzin Belajar Bagi Pegawai Negeri Sipil (SE MENPAN RB 4/2013),tentang ketentuan pemberian izin belajar dan tugas belajar kepada ASN.Pencapaian citacita ini dilaksanakan melalui dua program utama, yaitu: Penerapan kebijakan izin belajar dan tugas belajar bagi ASN (Aparatur Sipil Negara).

Faktor sumber daya sangat diperhitungkan terutama sumber daya manusia, untuk melihat keberhasilan penerapan kebijakan pimpinan atau kepal daerah tergantung dari pelasana kebijakan dibawahnya yaitu SDM atau Sumber Daya Manusia nya. Jika Sumber Daya Manusia nya memiliki kompeten dibidangnya sangat bagus maka tingkat produktifitas kinerja dilapangan akan lebih efektif dan efisien sehingga dapat menerapkan kebijakan-kebijakan yang diatur oleh pimpinan atau kepala daerah. Untuk meningkatkan SDM (Sumber Daya Manusia) tersebut pemerintah pusat melalui Surat Edaran MENPAN RB 4/2013 tentang ketentuan pemberian izin belajar dan tugas belajar kepada ASN.Maka berdasarkan hal diatas Pada tanggal 23 Desember 2020 peneliti melanjutkan kepada ibu Dinal Husan Sebagai Kabid PKA dengan pertanyaan apakah perlu atau tidak diterapkan kebijakan izin belajar dan tugas belajar untuk meningkatkan sumber daya manusia (SDM) di pemerintah kota pekanbaru,?, Ibu Dinal Husna langsung menjawab sesuai dengan kapasitasnya sebagai pimpinan bahwa:Kebijakan izin belajar dan tugas belajar dari pemerintah sangat di perlukan untuk meningkatkan SDM, karena tanpa jalur kebijakan tersebut kualitas SDM 
aparatur sipil negara (ASN) akan seperti berjalan ditempat, walaupun dibuat program pelatihan, workshop, seminar dan lainya tentang peningkatan sumber daya manusia (SDM) juga belum bisa menjamin itu semua.

Berdasarkan penjelasan ibu Kabid diatas maka kebijakan penerapan izin belajar dan tugas belajar sangat diperlukan bagi aparatur sipil negara (ASN) untuk meningkatkan sumber daya manusia (SDM), selanjutnya sesuai dengan lanjutan petanyaan sebelumnya, peneliti melanjutkan pertanyaan yaitu apakah penerapan kebijakan izin belajar dan tugas belajar bisa meningkatkan sumber daya manusia (SDM) bagi aparatur sipil negara (SDM) dilingkungan kota pekanbaru,? Pertanyaan diatas langsung dijawab oleh Ibu Dinal Husna, SH, M.Si (Kepala Bidang Pengembangan Kompetensi ASN) pada tanggal 22 Desember 2020 di kantor Badan Kepegawaian Daerah Kota Pekanbaru mengatakan bahwa : Kebijakan penerapan izin belajar dan tugas belajar sangat di perlukan oleh aparatur sipil negara (ASN) karena melalui kebijakan tersebut aparatur sipil negara (ASN) kota pekanbaru dapat mengasah dan meningkatkan kualitas sumber daya manusianya, selain itu kebijakan tersebut juga sangat diperlukan oleh aparatur sipil negara (ASN) sebagai pengakuan administrasi untuk menaikkan pangkat dan jabatan nya ke yang lebih tinggi dalam karirnya sebagai aparatur sipil negara (ASN).

Pertanyaan selanjutnya kepada Ibu Dinal Husna adalah apakah jenjang pendidikan juga mempengaruhi kualitas pekerjaan di suatu bidang kepegawaian,? Ibu Dinal Husna menjawab dengan sangat tegas bahwa :Jenjang pendidikan sangat mempengaruhi kualitas sumber daya manusia (SDM) bagi aparatur sipil negara (ASN) dalam bekerja di setiap bidang kepegawaian, contohnya ahliTechnology Informatika yang sudah Sarjana (S-1) maupun Magister (S-2) yang diangkat menjadi pegawai negeri sipil tentu lebih bagus dan berkualitas dibandingkan ahli Technology Informatika yang tamatan dari SMA dan SMK sederajat, kualitas itu dapat kita lihat dalam tugas sehari-hari dan pengalaman nya bekerja, serta dapat kita nilai dari hasil evaluasi job description yang diberikan oleh atasan masing-masing.

Peningkatan sumber daya manusia (SDM) aparatur sipil negara (ASN) di lingkungan kota pekenbaru dapat ditingkatkan dengan melanjutkan studi yang lebih tinggi melalui program kebijkan izin belajar dan tugas belajar yang diberikan oleh pemerintah. "Ibu Dinal Husna juga menambahkan bahwa bagi aparatur sipil negara (ASN) yang ingin melanjutkan studinya dengan program izin belajar juga tidak akan mempengaruhi jam kerja dan tupoksinya sebagai ASN, mereka juga masih dapat bertugas sambil kuliah atau belajar di kampus diluar jam dinas". peneliti juga sangat setuju dengan kebijakan ini, karena kebijakan penerapan izin belajar ini sangat bermanfaat bagi aparatur sipil negara (ASN) baik dari segi peningkatan keilmuan, finansial maupun dalam jenjang karir nantinya.

Pada tanggal 23 Desember 2020 peneliti juga mewawancarai ibu Ade Irma Suryani Kepala Sub Bidang Peningkatan Pendidikan PNS di Badan Kepegawaian Daerah Kota Pekanbaru mengatakan mengatakan bahwa : Pemerintah kota pekanbaru sudah menerapkan kebijakan izin belajar dan tugas belajar bagi ASN yang ingin melanjutkan studi yang lebih tinggi untuk meningkatkan sumber daya manusia yang unggul. Namun oleh sebab itu tentu ada faktor-faktor yang mempengaruhi kebijakan tersebut.

Ibu Ade Irma Suryani mengatakan faktor utama yang mempengaruhi ASN melanjutkan studi izin belajar dan tugas belajar adalah faktor keuangan, karena sampai saat ini pemerintah kota pekanbaru belum membuat kebijakan tenteng pemberian beasiswa bagi ASN yang melanjutkan studi izin belajar dan tugas belajar, namun ASN kota pekanbaru yang memiliki niat dan untuk meningkatkan SDM nya dan memiliki kemampuan dari segi finansial, maka mereka tetap melanjutkan studi dengan biaya pribadi. 
Pemerintah kota pekanbaru belum menunjukkan kepedulian untuk memberikan support kepada ASN yang melanjutkan studi, karena anggaran APBD kota pekanbaru yang cukup besar, hendaknya kota pekanbaru menganggarkan anggaran untuk peningkatan SDM ASN melalui program izin belajar dan tugas belajar.

\section{KESIMPULAN}

Dapat disimpulkan hal-hal sebagai berikut :

a. Proses penerapan kebijakan pemberian Izin Belajar dan Tugas Belajar, bagi ASN di lingkungan Pemerintah kota pekanbarau tidak berjalan sesuai ketentuan yang berlaku, dikarenakan di lapangan masih ada penyimpangan oleh ASN yang melanjutkan pendidikan, belum memenuhi persyaratan dan prosedur yang telah ditetapkan dalam kebijakan tersebut sebelum yang bersangkutan melaksanakan/ melanjutkan pendidikan. Implementasi proses dalam suatu kebijakan mencakup hal-hal sebagai berikut Organisasi, Interpretasi dan Penerapan. Apabila diperhatikan pada variabel organisasi, maka dapat disimpulkan dalam menjalankan suatu kebijakan diperlukan komitmen dari Wali Kota selaku pimpinan daerah, BKD dan Stake Holder lain yaitu Pimpinan SKPD, guna terlaksananya aturan atau hal-hal yang sudah ditetapkan dalam kebijakan pemberian program Ijin Belajar dan Tugas Belajar dengan baik. Berdasarkan variabel interpretasi dapat disimpulkan bahwa bagaimana ASN Pemroses Ijin Belajar dan Tugas Belajar menafsirkan atau memahami substansi kebijakan pemberian Ijin Belajar dan Tugas Belajar bagi ASN mengenai prosedur dan mekanismenya, sehingga dapat dipahami oleh ASN yang ingin melanjutkan pendidikan serta mengajukan Ijin Belajar dan Tugas Belajar, agar tidak terjadi penyimpangan dan pelanggaran, selain itu juga agar tercipta administrasi kepegawaian yang tertib. Sedangkan dari segi penerapan yaitu dalam implementasi kebijakan pemberian Izin Belajar dan Tugas Belajar bagi ASN, Pemroses program tersebut melaksanakan tugas pelayanan berpedoman pada pembagian/ uraian tugas masing-masing ASN di BKD Kota Pekanbaru dan Standar Operasional Prosedur (SOP) tentang pemberian Izin Belajar dan Tugas Belajar, agar tercipta kepuasan bagi ASN yang mengajukan permohonan dimaksud.

b. Masih terdapat faktor-faktor yang mempengaruhi implementasi kebijakan pemberian Izin Belajar dan Tugas Belajar, antara lainfaktor penghambat, diantaranya yaitu tidak lengkapnya halhal yang diatur dalam kebijakan pemberian Izin Belajar, sistem pengawasan yang masih rendah, tidak adanya komitmen, kurangnya keragaman Program Studi/Jurusan dan kurangnya kesadaran/ kepedulian. Sedangkan faktor pendukungnya antara lain yaitu mempunyai tujuan dan sasaran yang jelas, didukung oleh sumber daya yang memadai, pengaturan pengambilan keputusan yang jelas, sistem administrasi yang cepat dan motivasi lingkungan

\section{SARAN}

Saran Berdasarkan hasil penelitian ini, dapat disarankan beberapa hal sebagai masukan bagi Badan Kepegawaian Daerah Kota Pekanbaru antara lain:

1) BKD Kota Pekanbaru bersama Bidang Hukum Sekretariat Daerah, Wali Kota Pekanbaru dan DPRDKota Pekanbaru hendaknya membuat peraturan pemerintah daerah tentang penerapan kebijakan izin belajar dan tugas belajar untuk memperkuat landasan hukum dengan acuan dari MENPANRB. 
2) BKD Kota Pekanbaru hendaknya mengadakan sosialisasi membahas tentang kebijakan pemberian program Izin belajar dan Tugas Belajar dengan cara mengundang pimpinan unit kerja. Dalam pertemuan tersebut BKD Kota Pekanbaru menjelaskan tupoksi pimpinan unit kerja dalam program dimaksud dan menegaskan kepada pimpinan unit kerja harus melaksanakan seleksi secara internal bagi ASN yang ingin mengajukan program dimaksud, antara lain melaksanakan penilaian terhadap kompetensi, disiplin, dan motivasi ASN yang akan mengajukan permohonan pada program dimaksud

3) Pimpinan unit kerja diharapkan dapat memegang komitmen dengan penuh rasa tanggung jawab tentang apa yang telah disampaikan penulis pada point 2 (dua) di atas demi kemajuan Pemerintah Kota Pekanbaru

\section{DAFTAR PUSTAKA}

[1] S. Suwitri, "Konsep Dasar Kebijakan Publik MODUL 1,” Anal. Kebijak. Publik, no. 2, pp. 1-51, 2014.

[2] A. Ramdhani and M. A. Ramdhani, “Konsep Umum Pelaksanaan Kebijakan Publik,” J. Publik, pp. $1-12,2017$.

[3] M. Cleary, "Inovasi Kebijakan Publik," J. Chem. Inf. Model., vol. 53, no. 9, pp. 1689-1699, 2019.

[4] E. Landriany, "Implementasi Kebijakan Adiwiyata Dalam Upaya Mewujudkan Pendidikan Lingkungan Hidup di SMA Kota Malang," J. Kebijak. dan Pengemb. Pendidik., vol. 2, pp. 82-88, 2014.

[5] A. F. B. Adam, "Analisis implementasi kebijakan kurikulum berbasis lingkungan hidup pada program adiwiyata mandiri di SDN Dinoyo 2 Malang," J. Kebijak. dan Pengemb. Pendidik., vol. 2, no. 2, pp. 166-173, 2014.

[6] B. D. Kurniawan, "Implementasi Kebijakan Sertifikasi Guru Dalam Rangka Meningkatkan Profesionalitas Guru Di Kota Yogyakarta,” J. Gov. Polit., vol. 2, no. 2, pp. 259-278, 2011.

[7] H. K. Sulistyadi, "Implementasi Kebijakan Penyelenggaraan Layanan Pendidikan Inklusif di Kabupaten Sidoarjo," Kebijak. dan Manaj. Publik, vol. 2, no. 1, pp. 1-10, 2014.

[8] K. Negara, “Analisis Implementasi Kebijakan Penggunaan Antibiotika Rasional Untuk Mencegah Resistensi Antibiotika di RSUP Sanglah Denpasar: Studi Kasus Infeksi Methicillin Resistant Staphylococcus Aureus,” J. Adm. Rumah Sakit Indones., vol. 1, no. 1, p. 244383, 2014.

[9] P. Budiono, "Implementasi Kebijakan Badan Usaha Milik Desa ( Bumdes ) Di Bojonegoro ( Studi di Desa Ngringinrejo Kecamatan Kalitidu Dan Desa Kedungprimpen Kecamatan Kanor )," vol. 4, no. 1, pp. 116-125, 2015.

[10] D. Rahmat, "Implementasi Kebijakan Program Bantuan Hukum Bagi Masyarakat Tidak Mampu Di Kabupaten Kuningan,” UNIFIKASI J. Ilmu Huk., vol. 4, no. 1, pp. 35-42, 2017. 